\title{
Comparative Genetic Variability and Heritability in Some Tomato Varieties against Fruit Borer, Shape Disorders and Their Correlation
}

\author{
Muhammad Iqbal $^{1}$, Waqas Ahmad ${ }^{1, *}$, Jamil Shafi ${ }^{2}$, C. M.Ayub ${ }^{1}$, Muhammad Atiq ${ }^{2}$, Muhammad Shahid $^{3}$, \\ Muhammad Saleem ${ }^{4}$ \\ ${ }^{1}$ Institute of Horticultural Sciences, University of Agriculture, Faisalabad (38040) Pakistan \\ ${ }^{2}$ Department of Plant Pathology, University of Agriculture Faisalabad (38040) Pakistan \\ ${ }^{3}$ Department of Plant Breeding and Genetics, University of Agriculture Faisalabad (38040) Pakistan \\ ${ }^{4}$ Institute of Soil and Environmental Sciences, University of Agriculture, Faisalabad (38040) Pakistan \\ *Corresponding Author: uaf_waqas@yahoo.com
}

Copyright @ 2013 Horizon Research Publishing All rights reserved.

\begin{abstract}
Present study was carried out to determine the breeding potential ten tomato (Lycopersicon esculentum) varieties to develop resistant varieties for fruit borer, fruit cracking, blossom end rot, cat face, sunscald and blotchy ripening. Coefficients of variation, heritability and correlation coefficients were determined for this purpose. Significant varietal difference for all the resistant measured was observed. The coefficients of variability for phenotype were always greater then genotypic and environmental coefficients of variation for under study characters. High heritability for fruit borer resistant, cracked resist fruit, blossom end rot resist fruit, cat face resist fruit was observed. The positive significant relationships were obtain for Cracked resist fruit-Cat face resist fruit, Blossom end rot resist fruit-Sunscald resist fruit and Cracked resist fruit-Blotchy ripened resist fruit pairs.
\end{abstract}

Keywords Tomato, Genetic variability, Heritability, Correlations, Disorders

\section{Introduction}

Tomato (Lycopersicon esculentum M., $2 n=2 x=24$ ) is one of the Solanaceae fruit vegetable frequently eaten raw or cooked and processed whereas unripe green fruits are used for preparation of pickles and chutney [1]. It is important as a chief source of lycopene (an antioxidant), ascorbic acid and $ß$-carotene and also valued for its colour and flavor [2]. Varietal improvement demands a systematic study comprising identification and characterization of different varieties. It is not only important for utilizing the suitable trait, but also essential in the present time for protecting the distinctiveness of varieties [3]. The phenotypic appearance of the plant characters is primarily controlled by genetic constitution of a strain and the influence of environment on these characters, the genetic variance of any quantitative trait is composed of additive variance (heritable) and non-additive variance and include dominance and epitasis (non-allelic interaction) [4]). 22.39-37.79 \% loss in tomato yield was recorded in Karnataka state of India due to fruit borer (Helicoverpa armigera) [5]. The serious economic loss due to fruit cracking has been reported which degrade the fruit appearance. Susceptibility of tomato fruit to cracking was correlated with environmental and physiological factors as well as ultra structural and anatomical features [6]. Varity Juliet, Red pear and Red Grape are recommended as crack resistant varieties [7]. When fruits are forming, insufficient calcium uptake caused blossom end rot. Slight water soaked area near the blossom end of the fruit is a first symptom of blossom end rot. Usually the improper soil $\mathrm{pH}$ results calcium deficiency which ultimately cause the blossom end rot [9]. Glasshouse and field grown tomato are frequently subjected to a number of environmental and stress and microorganism, three terms blotchy ripening, gray wall and internal browning are general use [10]. Blotches on fruit, vegetables, or ornamental plants may have little effect on the quantity produce, the inferior quality of the product may reduce the market value so much that production is unprofitable or a total loss [11]. Blotchy ripening of tomato fruit can be describe as irregular or imperfect ripening, it has been known as a serious problem for some time, the percentage of blotchy fruits possibly will be reduced to less than 1 per cent, by appropriate applications of sulphate of potash and sulphate of ammonia [12]. In tomato nutritional, meteorological, and pathological factors affect the expression and severity of blotchy ripening disorders [13, 14]. The present studies was designed to estimate the coefficient of phenotypic variation (PCV \%), coefficient of genotypic variation (GCV \%), heritability and quantitative trait to measure the fruit borer resistant, Cracked resist fruit, Blossom end rot resist fruit, Cat face resist fruit, Sunscald 
resist fruit, and Blotchy ripened resist fruit in tomato. Precise heritability estimates obtained through present research will enable us to make estimates about the possible progress that can be achieved by making the more effective selection. This may ultimately lead to the choice of a breeding strategy most effective in supplementing the existing tomato improvement efforts to tackle the different problems. This research also provide the information on the resistant variation in the ten tomato genotypes assessed which can invariably serve as an index to selecting putative parents in breeding for new tomato varieties have more resistant against these disorders.

\section{Materials and Methods}

The understudy tomato population consisted of Nagina, Riogrande, Money Maker, Lyallpur, 88572, Picdeneto, Roma, CC Haus, Tibrido and Naqeeb. The nursery of the population was grown in a glasshouse and then transplanted in Horticulture Research Area, University of Agriculture Faisalabad, Pakistan. Experiment was laid out in a randomized complete block design with 4 replications. Data for fruit borer resistant, Cracked resist fruit, Blossom end rot resist fruit, Cat face resist fruit, Sunscald resist fruit, and Blotchy ripened resist fruit in tomato collected as formula given below.

$$
\text { \%Resistant Fruits }=\frac{\text { No. Unaffected Fruits }}{\text { Total No. of Fruits }} \times 100
$$

Phenotypic and genotypic coefficients of variation were calculated according to the formula given below:-

GCV $(\%)=$ Genotypic coefficient of variation

$$
\mathrm{GCV}=\frac{\sqrt{\sigma_{\mathrm{g}}^{2}}}{\overline{\mathrm{X}}} \times 100
$$

PCV $(\%)=$ Phenotypic coefficient of variation

$$
\operatorname{PCV}=\frac{\sqrt{\sigma_{\mathrm{P}}^{2}}}{\overline{\mathrm{X}}} \times 100
$$

Where:

$$
\bar{X}=\text { Grand mean of the trait }
$$

$\sigma^{2} \mathrm{p}=$ phenotypic variance

$\sigma^{2} \mathrm{~g}=$ genotypic variance

Broad sense heritability $\left(\mathrm{h}_{\mathrm{BS}}^{2}\right)$ for each recorded trait was calculated as a ratio of the genotypic variances to phenotypic variances.

$$
\mathbf{h}_{\mathrm{BS}}^{2}=\frac{\sigma_{\mathrm{g}}^{2}}{\sigma_{\mathrm{p}}^{2}}
$$

\subsection{Statistical Analysis}

The collected data of above mention resistant characters fruit for 10 varieties were subjected to ordinary analysis of variance in order to see whether the varietal differences were significant. For this analysis general linear model of STATISTA 8.1 Statistical package, was used. Coefficients of phenotypic and genotypic variance were calculated according to the formula given by Kwon and Torrie [15]. Broad-sense heritability $\left(h^{2}\right)$ was determined following [16]. Heritability percentage was categorized as demonstrated by Robinson et al [17] Low ( $0-30 \%)$, Moderate (30 - 60\%) and High (> 60\%). Correlation coefficient for different pairs of resistant fruit in tomato also determined. For this again Basic Statistic model of STATISTA 8.1 Statistical package, was used.

\section{Results}

Varietal (Table 1), statistical analysis (Table 2), genetic (Table 3) and correlation coefficient for different pairs of resistant fruit in tomato (Table 4) are shown in Tables. Significant varietal difference for fruit borer resistant, Cracked resist fruit, Blossom end rot resist fruit, Cat face resist fruit, Sunscald resist fruit, and Blotchy ripened resist fruit were obtain (Table 1). The Borer in fruit, Cracked effected fruit, Blossom end rot effected fruit, Cat face effected fruit, Sunscald effected fruit, Blotchy ripened effected fruit have shown in fig. 1 a, b, c, d, e and $f$ respectively.

\subsection{Borer Resistant Fruit}

Significant differences $(p \leq 0.05$ ) were observed among 10 tomato varieties for Borer resist fruit (Table 2). Range for Borer resist fruit found $77-88 \%$ in understudy varieties. Variety Nagina show maximum Borer resist fruit (88\%) and variety Riogrande was minimum (70\%). In this way we can suggested that Riogarnde was highly susceptible to Fruit borer attack as compare to other varieties (Table 1). Phenotypic coefficients of variation (PCV) and genotypic coefficients of variation (GCV) were 16.41 and 13.64, respectively (Table 3). Environmental coefficient of variation (ECV) was low (9.12) indicating that there was low effect of non-genetic factors on this trait thus this effect was not very high. Broad sense heritability $\left(h^{2}\right)$ for Borer resist fruit was high (69.11) which indicate substantial heritability of the character (Table 3). Borer resist fruit expressed positive and non-significant relationships with Cracked resist fruit $(\mathrm{r}=0.01)$ and Cat face resist fruit $(\mathrm{r}=19)$. It also expressed negative and non-significant relationships with Blossom end rot resist fruit $(r=-0.14)$ and Sunscald resist fruit $(r=-0.18)$. Blotchy ripened resist fruit was the only significant relationship with Borer resists fruit but this relationship was also negatively correlated $(r=-0.36)$ (Table 4). 

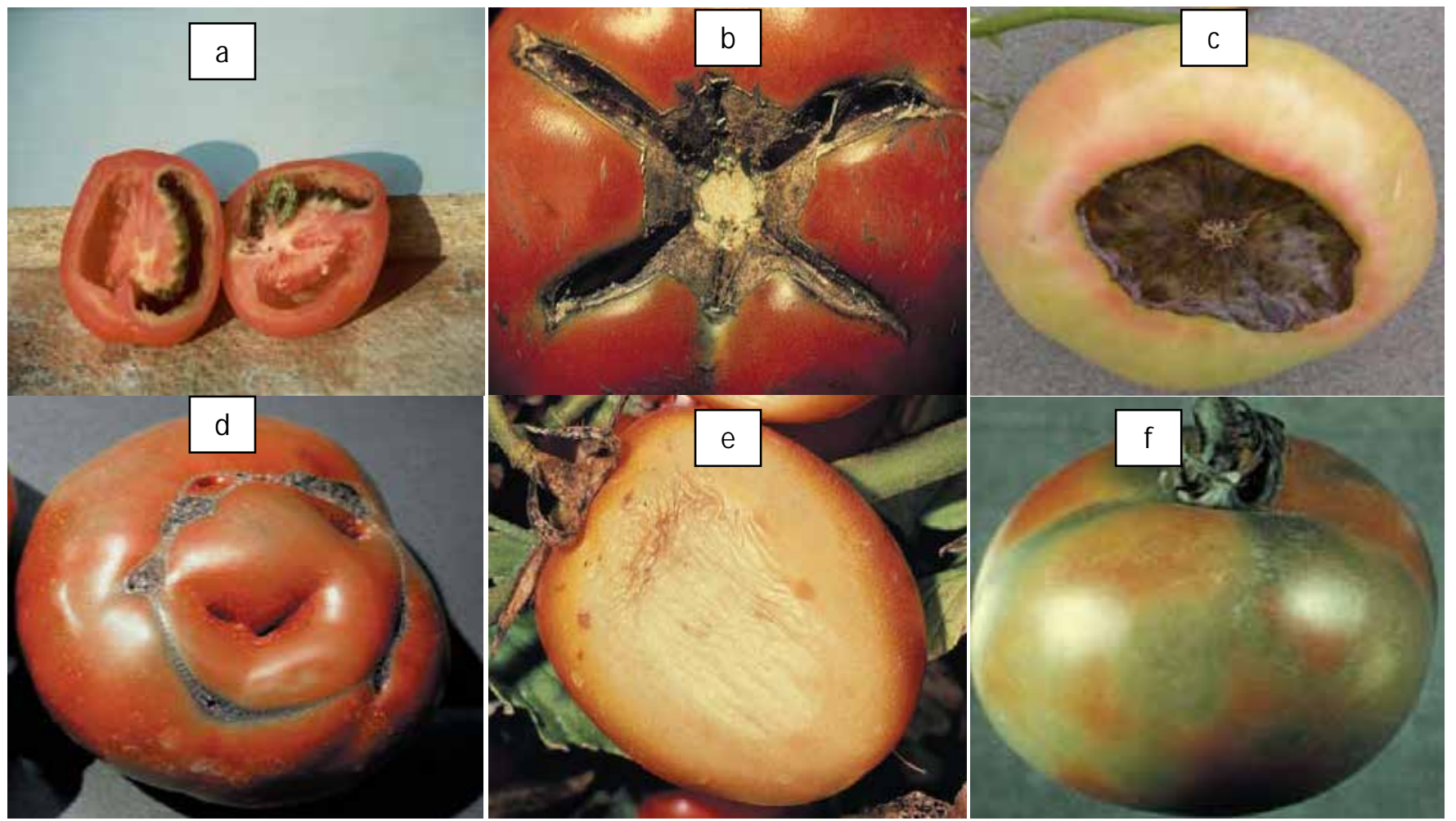

Figure 1. (a) Borer in fruit (b) Cracked effected fruit (c) Blossom end rot effected fruit (d) Cat face effected fruit (e) Sunscald effected t fruit (f) Blotchy ripened effected fruit

\subsection{Cracked Resistant Fruit}

Here again significant varietal differences at $(p \leq 0.05)$ were observed among 10 tomato varieties for cracked resist fruit (Table 2). Varity Roma possessed the maximum (98\%) resistant against fruit cracking. The minimum resistant (74\%) for fruit cracking was observed by Riogrande (Table 2). This low value of Riogrande for resistant indicates maximum susceptibility to fruit cracking. Coefficients of phenotypic and genotypic variations were 10.26 and 8.78 , respectively while ECV was low (5.31), broad sense heritability $\left(h^{2}\right)$ for cracked fruit was high (73.16) (Table 3). Significant positive correlation was observed for Cat face resist fruit and for Blotchy ripened resist fruit $(r=0.50, r=0.39$, respectively). Positive relationships also found for Blossom end rot resist fruit and for Sunscald resist fruit $(r=0.24, r=0.18)$ but these relationships were non-significant

\subsection{Blossom End Rot Resistant Fruit}

Analysis of variance table (Table 2) exhibited significant varietal differences for Blossom end rot resist fruit. The variety Money Maker had the maximum blossom end rot resistant (100\%) whereas variety Riogrande had minimum resistant (58\%) (Table 1). Slight difference in coefficient of phenotypic (19.21) and coefficient of genotypic (17.81) variations was observed. ECV was very low (7.18) as compared to PCV and GCV. Broad sense heritability for blossom end rot was very high (86.01) that indicate higher heritability of the character (Table 3). Positive significant correlations were found for blossom end rot resist with Cat face resist fruit $(r=36)$ and for Sunscald resist fruit $(r=58)$. Relationship with Blotchy ripened resist fruit was also positive but non-significantly correlated $(r=$ 0.08) (Table 4).

\subsection{Cat Face Resistant Fruit}

Analysis of variance based on mean square Cat face resist fruit in tomato varieties under study showed significant varietal differences (Table 2). The variety Naqeeb showed maximum Cat face resistant (98\%). The variety Riogrande showed the minimum (80\%) (Table 1). Estimation of GCV, PCV, ECV, and $h^{2}$, from these varieties were 5.63, 7.08, 4.30 and 0.18 , respectively for Cat face resistant (Table 3). Correlation coefficients of Cat face resist fruit with Sunscald resist fruit and with Blotchy ripened resist fruit were non-significant but were positively and negatively correlated, respectively ( $r=0.28, r=-0.05$, respectively) (Table 4$)$.

\subsection{Sunscald Resistant Fruit}

Statistical analysis of the data for \% Sunscald resist fruit revealed significant differences among varieties (Table 2). 
Variety Tibrido showed maximum resistant (98\%) for Sunscald as compare to other varieties understudy. Least resistant (78\%) was observed in variety 88572 (Table 2). The coefficients of variability for genotypic and phenotypic were 5.83 and 7.94, respectively. Here coefficients of environment was considerably equal (5.38) to GCV indicating that environment is playing equal role for the expression of this trait. Broad sense heritability for Sunscald was moderate (54.00) (Table 3). Correlation coefficient of Sunscald resist fruit with Blotchy ripened resist fruit pair of in tomato was non-significant and was negatively correlated $(r=-0.05)$ (Table 4).

\subsection{Blotchy Ripened Resistant Fruit}

Data pertaining to \% Blotchy ripened resist fruit subjected to analysis of variance (Table 1) showed significant varietal differences for this character. The variety Money Maker had blotchy resistant maximum (100\%) whereas the variety Picdeneto exhibited the least value for Blotchy resistant (84\%) (Table 2). Coefficients of genotypic, phenotypic and environmental variations, and broad sense heritability were 4.32, 6.85, 5.32 and 39.66, respectively for Blotchy resistant fruit (Table 3). Blotchy ripened resist fruit was the significant relationship with Borer resists fruit but this relationship was negatively correlated $(r=-0.38)$ (Table 4) 
Table 1. Borer, Cracked, Blossom end ret, Cat face, Sunscald and Blotchy ripened resist fruit of 10 Tomato Varieties.

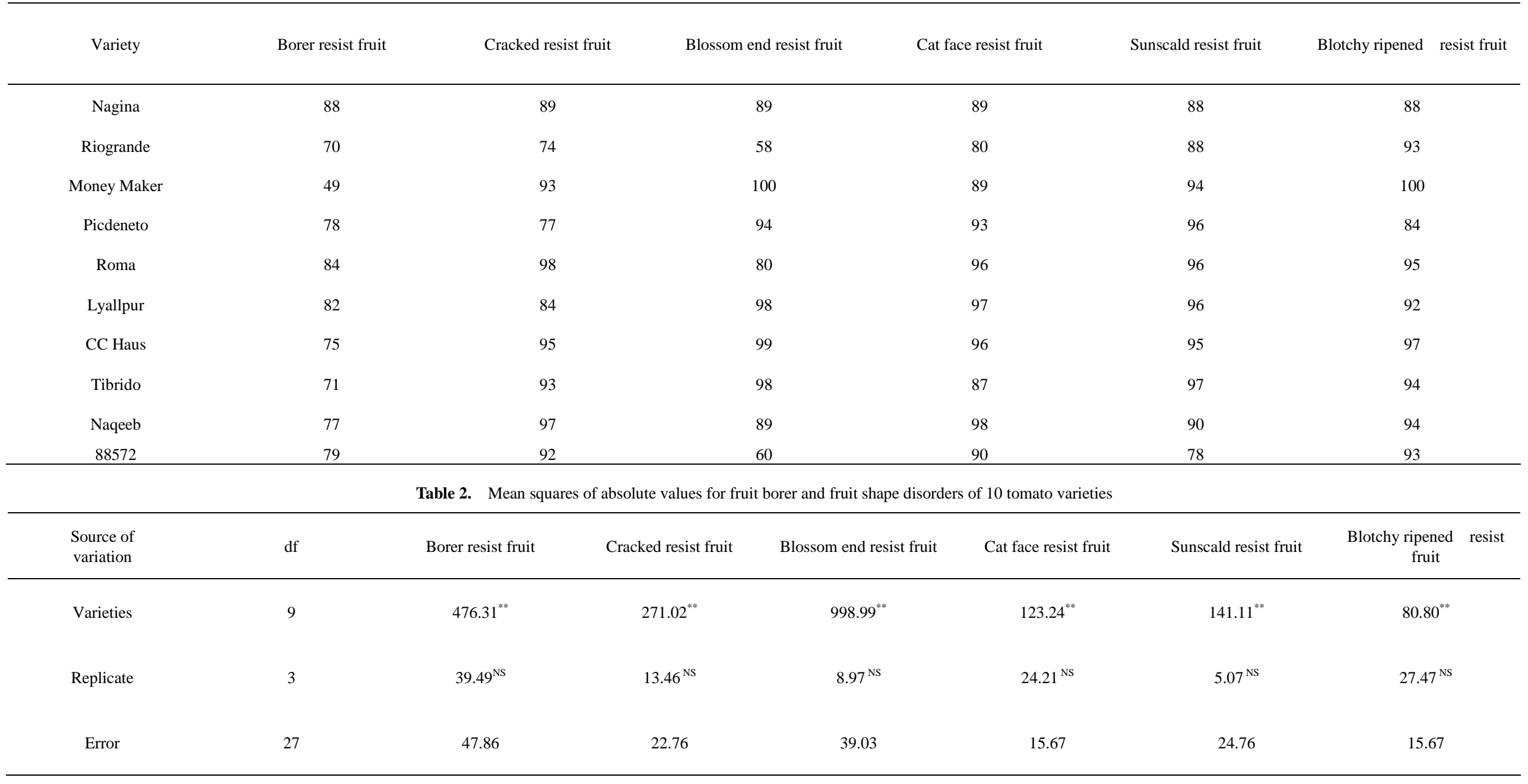

** indicates significant differences at $\mathrm{p} \leq 0.05, \mathrm{p} \leq 0.01, \quad$ NS indicates non-significant $(\mathrm{p}>0.05)$ 
Table 3. Statistical and genetic resistant against fruit borer and five fruit shape disorders of 10 tomato frit varieties.

\begin{tabular}{|c|c|c|c|c|c|}
\hline Component & Range & PCV & ECV & GCV & Heritability (\%) \\
\hline Borer resist fruit & 70.63-88.39 & 16.41 & 9.12 & 13.64 & 69.11 \\
\hline Cracked resist fruit & $74.80-97.23$ & 10.26 & 5.31 & 8.78 & 73.16 \\
\hline Blossom end rot resist fruit & $58.13-100.00$ & 19.21 & 7.18 & 17.81 & 86.01 \\
\hline Cat face resist fruit & 80.3575-98.59 & 7.08 & 4.30 & 5.63 & 63.18 \\
\hline Sunscald resist fruit & 78.785-97.08 & 7.94 & 5.38 & 5.83 & 54.00 \\
\hline Blotchy ripened resist fruit & $84.18-100.0$ & 6.85 & 5.32 & 4.32 & 39.66 \\
\hline
\end{tabular}

Table 4. Correlation coefficient for different pairs of \%resistant in tomato

\begin{tabular}{|c|c|c|c|c|c|}
\hline Character & Cracked resist fruit & Blossom end resist fruit & Cat face resist fruit & Sunscald resist fruit & Blotchy ripened resist frui \\
\hline Borer resist fruit & 0.01 & -0.14 & 0.19 & -0.18 & $-0.36^{*}$ \\
\hline Cracked resist fruit & & 0.24 & $0.50^{*}$ & 0.18 & $0.39^{*}$ \\
\hline Cat face resist fruit & & & & 0.28 & -0.05 \\
\hline Sunscald resist fruit & & & & & -0.05 \\
\hline
\end{tabular}

* Significant at 0.05 probability level 


\section{Discussion}

Varietal difference for all the resistant measured showed significant results (Table 2). In this way a wide variation obtain for the fruit borer and five different fruit disorders in the ten tomato genotypes assessed which can invariably serve as an index to selecting putative parents in breeding for new tomato varieties have more resistant against these disorders. In our finding variety Nagina showed highest resistant (88\%) against Fruit borer. In a study of 32 genotypes by Shashikanth [2] 21 genotypes were graded as moderately resistant showing 6 to 20 per cent fruit infestation and the other nine genotypes expressed 20 to 40 per cent fruit damage and were graded as susceptible, DVRT-2 show maximum resistant. Moderate value was observed for GCV and PCV for fruit borer resistant whereas $h^{2}$ was high. Here the coefficients of variability for phenotype always greater then genotypic and environmental coefficients of variation, which indicate that there was low effect of non-genetic factors for the entire understudy. Environment is playing very slight effect to develop these disorders as compare to genetic factors. Higher values of PCV indicate suitability for breeding which may be some time mislead to this selection due to non-genetic factors. Heavy irrigation or rain fall after long dry spell caused cracking [18]. Varity Roma possessed the maximum (98\%) resistant against fruit cracking and high heritability (76.16) observed for cracking. Blossom-end rot is caused by calcium deficiency and is more serious when an excess of nitrogen fertilizer has been applied [19]. The variety Money Maker had the maximum blossom end rot resistant (100\%) and high PCV, GCV and heritability was observed for maximum blossom end rot. GCV and PCV were found low for Cat face, Sunscald and Blotchy ripening. High, moderate and low heritability found for Cat face, Sunscald and Blotchy ripening, respectively. The positive significant relationships were obtain for the three pairs (Cracked resist fruit-Cat face resist fruit, Blossom end rot resist fruit-Sunscald resist fruit and Cracked resist fruit-Blotchy ripened resist fruit). Only the negative significant relationship were obtain for the single pairs (Borer resist fruit- Blotchy ripened resist fruit) (Table 4). The disorders which showed wider range of variation were also characterized by higher magnitudes of PCV and GCV as indicated by blossom end rot resistant (Table 3).

\section{REFERENCES}

[1] F. Naz, I.U. Haq, S. Asgar, A.S. Shah, A. Rehman. Studies on growth, yield and nutritional composition of different tomato cultivars in Battal valley of district Mansehra, Khyber Pakhtunkhaw, Sarhad, Journal of Agriculture, Vol.27, 569-571, 2011.
[2] Shashikanth. Genetic variability studies in tomato (Solanum lycopersicon Mill) wettsd. M.Sc (Hons.) Agri.Thesis. Department of Horticulture University of Agricultural Science, Dharwad, 2008.

[3] K. Vishwanath, K.P.R. Prasanna, H.M. Pallvi, P.S. Rajendra, P.J. Devaraju and T.V. Ananthararayanan. Identification of tomato (Lycopersicon esculentum) varieties through total soluble seed proteins. Research Journal of Agricultural Sciences, Vol.2, No.8-12, 2011.

[4] F. Al-Aysh, H. Kutma, A. Al-Zouabi. Genetic variation, heritability and interrelationships of some important characters in Syrian tomato landraces (Solanum lycopersicum L.), Academ Arena, Vol.4, No.10:1-5, 2012.

[5] N. Dhandapani, Shelkar, U.R., M.Murugan. Bio-intensive pest management (BIPM) in major vegetable crops: an Indian perspective. Food, Agriculture \& Environment, Vol.1, No.2, 333-339, 2003.

[6] Thompson, D.S. Extensiometric determination of the rheological properties of the epidermis of growing tomato fruit, Journal Experimental Biotechnology. Vol.52,1291-1301, 2001.

[7] Browning, Hodges, D.T., Lindgren. Selecting Tomatoes for the Home Garden, Online available at http://extention.unl.edu/publications.

[8] County, N. Home Grounds Fact Sheet. Cornell Cooperative Extension, Eisenhower Park, 2000.

[9] J.S. Boyle. Abnormal ripening of tomato fruit. Plant Diseases, Vol.78,936-944, 1994.

[10] G.N. Agrios. Plant Pathology, 5th ed. 525 B Street, Suite 1900, San Diego, California, UAS, 2005.

[11] W.F. Beweley, H.L. White. Some nutritional disorders of the tomato. Anal of Applied Biology, Vol.13, 323-338, 1926.

[12] D.M. Francis, S.A. Barringer, R.E. Whitmoyer. Yellow Shoulder Disorder in a Uniform Ripening Tomato Genotype, Hortscience, Vol. 35, Vol.6, 1114-1117, 2000.

[13] S. Hanif-Khan, R.C. Bullock, P.J. Stoffella, C.A. Powell, J.K. Brecht, H.J. McAuslane, R.K. Yokomi. Tomato irregular-ripening symptom development and ripening of silver leaf whitefly-infested dwarf cherry tomatoes. Journal of American Social Horticultural Science, Vol.123,119-125, 1998.

[14] S.H. Kwon, J.H. Torrie. Heritability and interrelationship among traits of two soybean populations, Crop Science, Vol.4, 196-198, 1964

[15] Falconer, D.S. and T.F.C. Mackay. Introduction to Quantitative Genetics. Chapman and Hill, London, 1996.

[16] H. F. Robinson, R. E. Comstock, and V. H. HarveyEstimates of heritability and degree of dominance in corn, Agronomy Journal, Vol.4, 353-359.

[17] A.F. Baloch. Vegetable crops. In: Horticulture (Ed. M.N. Malik) Shuja Sons Printers, Islamabad, p. 510, 1994.

[18] Mark, L.G and Brooke A.D. Tomato diseases and disorders. Department of Plant Pathology, Lowa State University, 2006. 